\title{
sciendo
}

\section{Impact of the covid-19 crisis on global financial imbalances}

\author{
Valentina Fetiniuc \\ International Institute of Management IMI-NOVA \\ email:valentinafetiniuc@yahoo.com \\ Ivan Luchian \\ International Institute of Management IMI-NOVA \\ email: luchian_ivan@mail.ru
}

\section{DOI: $10.2478 /$ gssfj-2020-0011}

\begin{abstract}
Following the synthesis of theories related to the mechanisms of international financial crises, authors Kovalev and Paseko developed the Model of global imbalance synergy, which substantiates the idea of generating economic and financial crisis situations globally by manifesting the chain of different imbalances. The model starts from global monetary and demographic imbalances, which determine the imbalances between real and financial sector of global economy, as well as real and market values of transnational companies. Together they all lead to imbalances in the distribution of global wealth in industrially developed and developing countries, as well as imbalance between consumption and income in industrially developed countries. Studies in this area have demonstrated the viability and usefulness of this model. The current situation tends to make some clarifications in this model. First of all, it is about the onset of a pro-cyclical economic crisis in 2018, against the background of which in 2020 an economic crisis of a pandemic nature began. Secondly, the latter tends to exacerbate global imbalances, which may ultimately trigger a global financial crisis. The situation is exacerbated by global trade conflicts with negative consequences, continued currency clashes and inflated financial bubbles. This situation requires urgent remedial actions at the global level.
\end{abstract}

Keywords: global imbalance, pandemic crisis, economic crisis, financial crisis

\section{Introduction.}

In recent decades, numerous studies have been conducted related to international financial crises, and a solid body of related information has been accumulated, which allows a generalization of the theoretical concepts formulated.

Based on the summary of results of examined theories, authors Kovalev and Paseko (2013) formulated the Generalized Model of the Synergy of Global Imbalances, which, in our opinion, can become an efficient tool in predicting new international financial crises. In a narrow sense, imbalances in the world economy are associated with inequality in the exchange of economic resources between countries of world. 
In a broad sense, global imbalances mean different types of global relations between elements of the world economy, which have certain negative aspects, ie they have some negative consequences for economy as a whole, taken on a global scale or for some regions of world (or certain countries). (Bajan, 2013)

The Generalized Model of Global Imbalances Synergy is based on the recognition of existence of different nature global imbalances, which are interconnected through different transmission channels. Following the composition of their impact, the synergy effect is obtained, which makes it inevitable to trigger new financial crises.

The same idea can be deduced from works of the International Monetary Fund specialists since 2011 (MBФ..., n.d.) until now (IMF, 2020), being highlighted following global imbalances in the context of the COVID-19 crisis:

- Imbalances caused by current account surpluses and deficits;

- Imbalances related to investment position and official reserve assets of different countries;

- Movements of exchange rates, including nominal and effective;

- Changes in trade and other branches of global economy;

- The impact of crisis on the balance of remittances.

Being examined in the light of economic and financial events during 2018-2020, in our opinion, the model is to be adapted to the current situation in the form presented in Figure 1.

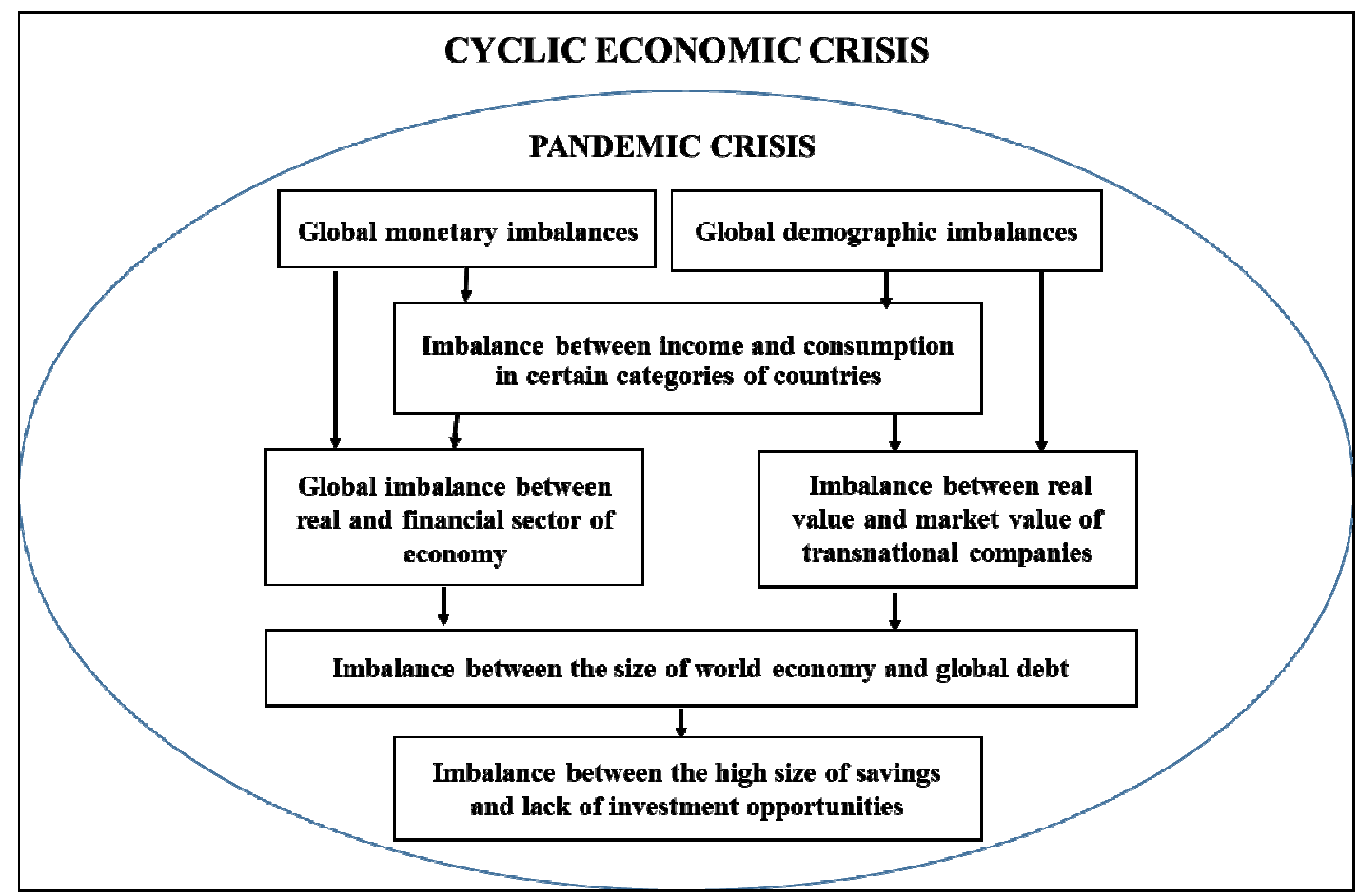

Figure 1. Generalized model of global imbalances synergy (Source: in the base (Kovalev, Paseko, 2013) 


\subsection{Research Methods.}

Research carried out in the first place was based on the descriptions of existing global financial imbalances contained in various bibliographic sources. Then the generalized model of global imbalance synergy was tested. The study was then deepened by studying the functioning of mentioned model in the conditions of pro-cyclical global economic crisis and COVID-19 pandemic crisis. Obtained results were presented in this article.

\subsubsection{Analysis Result.}

The research shows that the impact of global imbalances on global financial system stability is multifaceted.

First, it is necessary to address global monetary imbalances expressed by following issues:

- Maintaining dominant position of US Dollar on the global financial market;

- Deepening the problem known as the "Triffin Dilemma";

- Postponement of introduction of a global currency.

So far, the Forex market is dominated by US Dollar, whose share in the total volume during 1998-2019 ranged between $84.9 \%$ and $89.9 \%$.

Official foreign exchange reserves in US dollars increased from $\$ 1.4$ trillion in 2000 to $\$ 6.7$ trillion in 2019 , or 4.9 times. However, their share in the total volume of official foreign exchange reserves decreased from $71.1 \%$ to $61.8 \%$, ie by 9.3 pp. (Reserve..., n.d.), (Watson, 2019)

Over $80 \%$ of world trade turnover is expressed in US dollars. According to Bloomberg, the US dollar approximately accounted for $40 \%$ of interbank turnover in the SWIFT system. (Aorrap..., n.d.)

Triffin Dilemma put it this way: "In order to provide central banks in other countries with the amount of dollars needed to form national foreign exchange reserves, it is necessary for the United States to have a constant balance of payments deficit. But a balance of payments deficit undermines confidence in USD and reduces its value as a reserve asset, so a balance of payments surplus is needed to increase confidence". The trend of continuous growth in the volume of international trade and services provided internationally requires a continuous increase in available liquidity, including in US dollars.

Thus, the volume of world trade increased from $\$ 5.2$ trillion in 2000 to $\$ 19.5$ trillion in 2018. (Trends..., n.d.)

The volume of professional services provided in 2018 globally reached the level of 5.7 trillion USD, increasing with an average annual rate of $7.4 \%$ from 2018 , and by 2022 the level of this indicator is expected to be 8.1 trillion USD. (The 2019..., n.d.)

The continued growth of the global financial market must also be taken into account. But the additional issuance of the US Dollar leads to long-term its weakening, undermining its position as a global reserve currency.

To mitigate consequences of pandemic crisis, additional emissions takes place through the purchase of government bonds and commercial papers with mortgage backing. The total volume of transactions will amount to $\$ 4.3$ trillion in 2020 . (Trofimov, 2020) 
It should also be noted that no serious progress has been made in the last decade in developing a single global currency. The introduction of Bitcoin has not been recognized as a related solution either.

Also, an important factor of destabilization is expressed by global demographic imbalances, whose main aspects are the following:

- Substantial gap in the global distribution of free labor;

- Uneven acceptance of knowledge-based society establishment;

- Gap increasing in the welfare level of different countries population;

- Problems of migrant flows channeling.

At present, the basic share of human resources in the world (59.8\%) is concentrated in Asia (4.6 trillion inhabitants), producing a share of 36\% of global GDP. (World population, n.d.),

The problem of labor surplus in this region is partially solved by stimulating investments in various branches of economy, including by attracting foreign direct investment, which in 2019 amounted to $\$ 473$ billion (33.9\% of global volume). (World Investment..., n.d.)

Another effective solution has proved to be the outsourcing of many economic activities from companies from industrially developed countries to developing countries.

But the basic solution to the nominated problem remains the migration of cheap labor from countries with a high level of poverty to countries with developed economies. In the isolation conditions imposed by the pandemic, it is expected that the traditional mechanisms of labor migration will work much more complicated.

The differentiation of economic development level is also determined by extremely uneven constitution of knowledge-based society, which examines research and advanced technologies as important factors of competitiveness. In this context, the successes of industrially developed countries are remarkable and in the field of research and development world leaders are USA, China and Japan.

Until now, the differentiation of global population distribution and level of GDP are preserved, which is demonstrated in Table 1. 


\begin{tabular}{|c|c|c|c|c|}
\hline Categories of countries & $\begin{array}{c}\text { GDP } \\
\text { (USD } \\
\text { billion) }\end{array}$ & $\begin{array}{l}\text { Share } \\
\text { in } \\
\text { global } \\
\text { GDP } \\
(\%)\end{array}$ & $\begin{array}{l}\text { Population } \\
\text { (millions } \\
\text { of people) }\end{array}$ & $\begin{array}{l}\text { Share in } \\
\text { global } \\
\text { population } \\
(\%)\end{array}$ \\
\hline $\begin{array}{l}\text { Countries of "golden billion" } \\
\text { (United States, Japan, United } \\
\text { Kingdom, Australia, Canada, } \\
\text { European Union) }\end{array}$ & 52128.5 & 59.4 & 1079.2 & 14.0 \\
\hline $\begin{array}{l}\text { Countries of "silver billion" } \\
\text { (China, India, Brazil, Russian } \\
\text { Federation and „Asian } \\
\text { tigers") }\end{array}$ & 23138.2 & 26.4 & 3221.6 & 41.8 \\
\hline Rest of world & 12484.9 & 14.2 & 3412.7 & 44.2 \\
\hline Global level & 87751.6 & 100.0 & 7713.5 & 100.0 \\
\hline
\end{tabular}

Table 1: Population and global GDP distribution by country categories (Sources: (Kovalev, Paseko, 2009), (Gross..., n.d.), (List.., n.d.))

It is remarkable that the discrepancy in the well-being of "golden billion" countries with the rest of world tends to increase. At the same time, it is important the productivity level raising of "silver billion" countries.

Those mentioned, lead to some extent the imbalance between income and consumption in certain categories of countries.

During the analyzed period, some countries, due to their economic and financial specialization, position themselves as large exporters, and others - as importers, which contributes to generation of economic and financial problems, including the formation of official reserve assets and chronic global debt growth.

This can also be seen by the dynamics of current account balances. In this context, there is a chronic discrepancy between two groups of countries. (IMF, 2020)

The first group refers to countries with a chronic current account surpluses. They include China, Japan, Germany, the Netherlands, oil exporting countries and others. The second group refers to countries with chronic current account deficits and which includes the United States, Great Britain, some Eurozone countries, developing countries and others.

Since 2004, there has been a positive discrepancy as the difference between the total amount of current account deficits and their surpluses.

In 2019 the global current account balance (expressed as sum of all surpluses and deficits) constituted 2.9 percent of world GDP. (IMF, 2020)

An important issue has become the global imbalance between real and financial sector of economy.

In order to explain the problem given for the beginning, it is necessary to present certain data:

- The level of global stock market capitalization was approximately $\$ 90$ trillion, increasing with $\$ 17$ trillion in total value in 2019. (Ross, 2020), (Jesse, 2019)

- In 2019, the volume of the global economy was estimated at $\$ 133$ trillion, increasing by $\$ 13$ trillion compared to 2017. (Hamadehmizuki, Purdie, 2020) 
- The level of capitalization of the global banking market amounted to $\$ 7.9$ trillion in 2019, and in 2018 the total amount of assets of the banking industry was $\$ 124$ trillion. (Coronavirus..., n.d.)

- Global premiums insurance companies in 2019 reached \$6.3 trillion. (World Insurance..., n.d.)

- The size of professionally managed global real estate investment market has increased from \$ 8.9 trillion in 2018 to $\$ 9.6$ trillion in 2019. (Real estate..., n.d.)

Mention should also be made of financialization process, which is a form of functioning of economy, characterized by the predominance of financial transactions in the general structure of domestic and international relations and the subordination of real sector of economy to financial one. (Osik, 2014)

Financialisation can be defined as systemic and growing power of finance and financial engineering.

The modern capitalist development can ignore the magnitude of financial sector growing expansion. The discrepancy between these segments of economy has been pronounced especially in countries with developed market infrastructure.

The significant gap between real and financial sectors of economy is highlighted by the high share of financial sector in total revenue, while the share of financial sector in GDP is relatively low. (Osik, 2014)

An imbalance between financial sector and industrial production is also observed in countries with economies in structural transformation, which include the BRICS countries. In these countries, the demand for financial resources is growing faster than GDP for following reasons:

- In most of these countries there is an increase in industrial production, which requires significant financial resources;

- The need to implement significant infrastructure projects generates a growing demand for financial resources needed for their implementation;

- The involvement of millions of low- and middle-income households in financial transactions generates a further increase in the demand for financial resources, including credit.

Another important issue remains the imbalance between real and market value of transnational companies.

The number of transnational corporations in the world is constantly growing. If in 1970 it constituted 7000 units, at the beginning of 1990s - 37000 units and in 2006 77000 units. Also, the number of foreign affiliates is constantly growing.

Overall, TNCs supplie about $50 \%$ of world industrial production. TNCs account for more than $70 \%$ of world trade and $40 \%$ of this trade takes place within TNCs, ie they do not take place at market prices, but at so-called transfer prices, which are not formed under market pressure, but under the long-term policy of the parent corporation. TNCs have very large budgets that exceed budgets of some countries. After the lifting of investment restrictions at the end of last century, the surplus of speculative capital flows from Transnational Banks was directed to global stock markets, suddenly inflating the value of corporations. The increase in indices (average cost of elite enterprises for country) has been detached from balance sheet capital tens of times. The value of other American banks and investment firms was tens of times higher than their regulatory capital and annual profit. (Kovalev, Paseko, 2009) 
The first warning signal of such a situation was given by destruction of Dotcom's market value at the beginning of millennium was not heard - the volume of trading on securities market has increased 20 times in the last 10 years.

An important threat to international financial stability has become the imbalance between the size of world economy and global debt.

Recessionary conditions caused by pandemic caused the global debt to GDP to reach a new record of $331 \%$ in the first quarter of 2020 , compared to the level of $320 \%$ at the end of 2019. In monetary terms, it is $\$ 258$ trillion. (Global..., n.d.)

We also consider it necessary to highlight the imbalance between the high size of savings and the lack of investment opportunities.

Since 2012, the global financial market is in a state of excess liquidity, when its level was about $\$ 3$ trillion. Of these $\$ 3$ trillion, about $\$ 1$ trillion is concentrated in US, eurozone, Japan and UK, with the rest being in emerging markets.

A new impact factor on global imbalances has become the pandemic crisis, which is manifested by the following:

- Economic consequences of pandemic crisis;

- Some manifestations of financial crisis;

- The impact of anti-crisis measures.

In the opinion of many economists, "COVID-19 is more than a health crisis, with unprecedented socio-economic implications. The pandemic is disrupting every country it affects, with the power to generate devastating social, economic and political effects that will leave deep scars." (Pandemia..., n.d.)

The world community is currently facing an unprecedented pandemic cataclysm. Human history has repeatedly experienced pandemic crises, but they have had a regional character, while the current one is the first with a truly global character.

After the rapid spread of infectious diseases called COVID-19, the global health care system received a catastrophic blow, with the number of sick people increasing. Of course, this process will also have important economic and financial consequences in the form of losses caused by the inability to work of a large number of patients, as well as increased costs for the maintenance of the medical system. On the other hand, isolation measures, unlike most countries, have led to significant bottlenecks in the operation of international trade and logistics systems, as well as the cessation of many economic activities.

The evolutionary model of global pandemic crisis is presented in Figure 2 as anatomy of current economic and financial crisis.

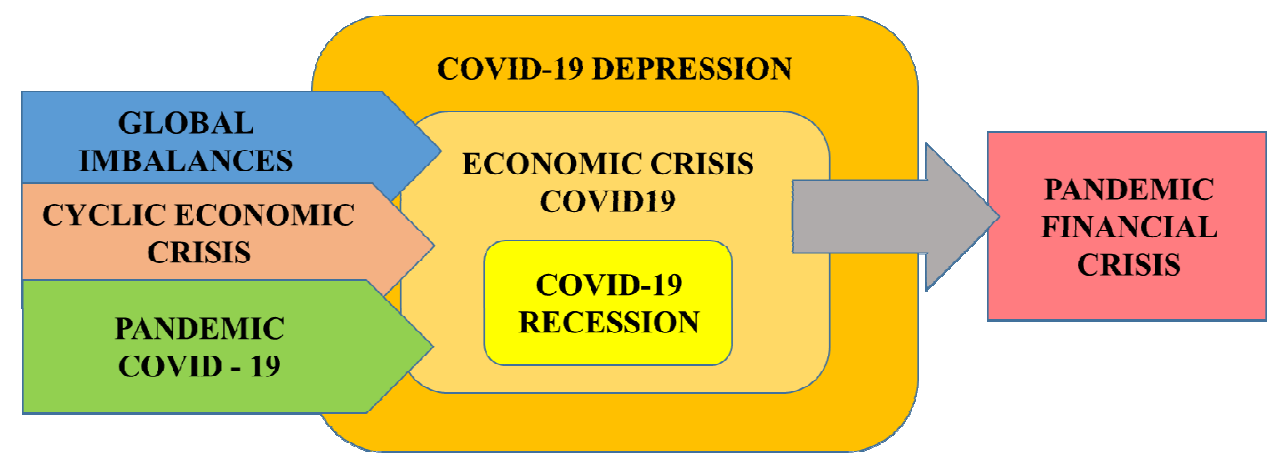

Figure 2. The anatomy of current economic and financial crisis (developed by the authors) 
At present, specialists talk about the COVID-19 Recession, which can be expressed by a decrease in production, a reduction in investment, a temporary stagnation of business, being a phase of decline in economic activity and a temporary decrease in economic activity at worldwide under the influence of the SARS-CoV-2 virus pandemic, its consequences, as well as measures to prevent its spread based, in large part, on isolation. (COVID-19..., n.d.)

But over time it can evolve into economic crisis COVID-19. It can manifest as a period of economic decline, which is the result of the influence of a complex of factors and has its roots in the cyclical economic crisis triggered in December 2018. (Мировой..., n.d.)

Pessimistic experts talk about the COVID-19 Depression, which can manifest itself as a long-term economic collapse, as a result of global pandemic as a catalyst for economic and financial cataclysms whose potential was accumulated a few years ago, being characterized mainly of a significant rise in the unemployment rate, restriction of credit, major restriction of industrial production and investment, hyperinflation, numerous bank failures, significantly reduced trade, a very volatile and unpredictable exchange rate, mainly with the trend of devaluation, reduction demand for goods and services, increasing production costs, reducing production volume, decreasing rate of profit, reducing living standards of population. (The Next...)

In addition to the above, the COVID-19 pandemic crisis has generated a complex of financial problems:

- Global disturbances in the capital markets and the international foreign exchange market. The COVID19 pandemic, as well as the resulting economic crisis, is spreading unevenly in the global economic space, which has caused important changes in the formation of foreign exchange rates of different countries. Thus, in the period 20.03.2020-19.08.2020 the exchange rate of the US Dollar against the Euro decreased by 12.1\%. (Finance..., n.d.) Also, between February and March 2020, the global stock market crashed. In particular, the S\&P500 Index decreased by $33.9 \%$ (S7P500 ... n.d.), the EuroStoxx50 Index decreased by $38.23 \%$ (EURO..., n.d.), and the TOPIX Index decreased by $27.2 \%$ (Tokyo..., n.d.);

- Significant reduction in the volume of direct investments. The pandemic crisis will most likely lead to a fall below $\$ 1$ trillion level by 2020 (UNCTAD, 2020).

- Increasing demand for shelter assets. In particular, in 2020 world gold prices set a historical record of 2070 USD/ ounce. (Gold..., n.d.)

Inevitably, these problems will affect the functioning of global banking system and global insurance systems.

The COVID-19 crisis has generated a new form of global imbalances - of anti-crisis economic and financial measures. At the moment, the discrepancy between the industrially developed and the developing countries becomes evident in view of the economic-financial intervention of the central authorities for mitigating the consequences of the global pandemic crisis. But the development of these measures required the mobilization of additional funds in the form of loans, which, in turn, led to a worsening of global debt problem. 


\section{References}

Coronavirus likely to dent major global economies, industries. Available: https://www.thenews.com.pk/print/639139-coronavirus-likely-to-dent-major-globaleconomies-

industries\#: :text=The $\% 20$ “Investopedia" $\% 20$ writes $\% 3 \mathrm{~A} \% 20$ “, banking $\% 20$ industry $\% 20 \mathrm{w}$ ere $\% 20 \% 24124 \% 20$ trillion" (December 7, 2020)

COVID-19 recession. Available: https://en.wikipedia.org/wiki/COVID-19_recession (October 6, 2020)

Economy of Asia. Available: https://en.wikipedia.org/wiki/Economy_of_Asia, December 2, 2020)

EURO STOXX 50 Price EUR. Available:

https://www.bloomberg.com/quote/SX5E:IND (October 7, 2020)

Finance Yahoo. Available:

https://finance.yahoo.com/quote/EURUSD=X?p=EURUSD=X\&.tsrc=fin-srch (October 10, 2020)

Global debt hits record high of 331\% of GDP in the first quarter of 2020: IIF. Available: https://economictimes.indiatimes.com/news/international/business/global-debt-hitsrecord-high-of-331-of-gdp-in-q1-iif/articleshow/77000231.cms (December 27.10.2020] Gold Price. Available: https://goldprice.org (October 09, 2020)

Gross domestic product 2019, Available:

https://databank.worldbank.org/data/download/GDP.pdf, , (December 2, 2020)

Hamadehmizuki, Nada; Purdie, Yamanakaedie (2020) The size of the world economy in 2019: A baseline from which to measure the impact of COVID-19 and track economic recovery, Available: https://blogs.worldbank.org/opendata/size-world-economy-2019baseline-which-measure-impact-covid-19-and-track-economic-

recovery\#: :text=Main\%20findings,current\%20US\%20dollars\%20in\%202017 (December 7, 2020)

International Monetary Fund (2020) External Sector Report: Global Imbalances and the COVID-19 Crisis. Available:

https://www.imf.org/en/Publications/ESR/Issues/2020/07/28/2020-external-sectorreport (October 20, 2020)

List of countries by population (United Nations). Available:

https:/ / en.wikipedia.org/wiki/List_of_countries_by_population_(United_Nations), (December 01, 2020)

Pandemia COVID-19. Umanitatea are nevoie de liderism și solidaritate pentru a învinge COVID-19. Available:

https://www.md.undp.org/content/moldova/ro/home/coronavirus.html (October 6, 2020)

Pound, Jesse (2019) Global stock markets gained \$17 trillion in value in 2019. Available: https://www.cnbc.com/2019/12/24/global-stock-markets-gained-17-trillion-in-value-in2019.html\#: : text $=$ The $\% 20$ value $\% 20$ of $\% 20$ the $\% 20$ global,significant $\% 20$ part $\% 20$ of $\% 20$ th e\%20gains (December 7, 2020)

Real estate market size 2019. Available: https://www.msci.com/documents/10199/035f2439-e28e-09c8-2a78-

4c096e92e622\#: :text=Market $\% 20$ size $\% 20$ increased $\% 20$ in $\% 202019$, to $\% 20 \% 249.6 \% 20$ trill ion\%20in\%202019 (December 07, 2020)

Reserve currency. Available: https://en.wikipedia.org/wiki/Reserve_currency (December $1,2020)$ 
Ross, Sean (2020) Financial Services: Sizing the Sector in the Global Economy. Available: https://www.investopedia.com/ask/answers/030515/what-percentage-global-economycomprised-financial-services-sector.asp (December 7, 2020)

S\&P 500 Index. Available: https://www.bloomberg.com/quote/SPX:IND (October 7, 2020)

The 2019 Global Professional Services Market - Worth \$5.7 Billion in 2018; Projected to Surpass $\$ 8$ Billion by 2022. Available:

https://www.businesswire.com/news/home/20190701005419/en/The-2019-GlobalProfessional-Services-Market---Worth-5.7-Billion-in-2018-Projected-to-Surpass-8-Billionby-2022---ResearchAndMarkets.com (December 3, 2020)

The Next Global Depression Is Coming and Optimism Won't Slow It Down. Available: https://time.com/5876606/economic-depression-coronavirus/ (October 7, 2020)

Tokyo Stock Exchange Tokyo Price Index TOPIX. Available:

https://www.bloomberg.com/quote/TPX:IND (October 7, 2020)

Trends in global export volume of trade in goods from 1950 to 2018. Available:

https://www.statista.com/statistics/264682/worldwide-export-volume-in-the-trade-since1950/\#: : text $=$ Trade $\% 3$ A $\% 20$ export $\% 20$ volume $\% 20$ worldwide $\% 201950$ -

2018\&text=In $\% 202018 \% 2$ C $\% 20$ the $\% 20$ global $\% 20$ trade,trillion $\% 20$ U.S. $\% 20$ dollars $\% 20$ in $\% 202000$ (December 3, 2020)

UNCTAD (2020) Global foreign direct investment projected to plunge 40\% in 2020 .

Available: https://unctad.org (October 9, 2020)

Watson, Casey (2019) The world's most powerful reserve currencies. Available:

https://www.finance101.com/the-worlds-most-powerful-reserve-currencies/ (December 1, 2020)

World Insurance Marketplace. Available: https://www.iii.org/publications/insurancehandbook/economic-and-financial-data/world-insurance-marketplace (December 7, 2020)

World Investment Report 2020. Available: https://unctad.org/webflyer/world-investmentreport-2020 (December 3, 2020)

World population. Available: https://en.wikipedia.org/wiki/World_population (December 3, 2020)

Бажан, А.И. (2013) ГАобальные Аисбалансы: содержание и формы. Available:

http://www.instituteofeurope.ru/images/uploads/doklad/288.pdf (November 20, 2020)

Аомлар США. Available: https://ru.wikipedia.org/wiki/_омлар_США. (November 25, 2020)

Ковалев, М.М.; Пасеко, С.И. (2009) Международные и национальные барьеры кризису. Available: https://library.fes.de/pdf-files/bueros/belarus/07068.pdf (December 12, 2020)

Ковалев, Михаих; Пасеко, Сергей (2013) Мировой кризис и механизмы защиты от внешних влияний на финансовую стабильность страны, Банки и Экономика, № 2324, c, 9-29, 30.08.2013. Available: https:/ / elib.bsu.by/bitstream/123456789/154564/1/549313.pdf (December 12, 2020) МВФ: ГАобальные Аисбалансы могут спровоцировать новый кризис. Available: https://www.rbc.ru/economics/01/02/2011/5703e2ed9a79473c0df19c5a (October 20, 2020)

Мировой экономический кризис начался задолго до пандемии. Available: https://www.mk.ru/economics/2020/07/05/mirovoy-ekonomicheskiy-krizis-nachalsyazadolgo-do-pandemii.html (October 08, 2020) 
Geopolitical, Social Security and Freedom Journal, Volume 3 Issue 2, 2020

Осик, Ю.И. (2014) Аеглобализация мировой экономики как следствие ее финансиализации. Available: https:/ / applied-research.ru/ru/article/view?id=4625, (October 28, 2020)

Трофимов, Георгий (2020) Количественное смягчение рискует ослабить Аолмар. Available: https://expert.ru/expert/2020/27/kolichestvennoe-smyagchenie-riskuet-oslabitdollar/ (December 2, 2020) 